\title{
Impact of Prices on Paddy Performance in Eastern Vidarbha Zone
}

\author{
Nishant V. Shende* \\ Department of Agricultural Economics \& Statistics, Dr. PDKV, \\ Akola, Maharashtra (444104), India \\ *Corresponding author
}

\section{A B S T R A C T}

\section{Keywords \\ Rice (Oryza sativa L.), Paddy cultivation}

\section{Article Info}

Accepted:

24 July 2020

Available Online: 10 August 2020
Agriculture plays an important role in rural development. Rice is the more popular staple food of more than 80 per cent of the world population. It contributes 42 per cent of the total food production in India. The present study is based on secondary time series data. The compound growth rates, instability and standard cost concepts were use for the present study. It concluded that the compound growth rates for area were positive for all most all the district of EVZ except Gondia. The growth rates of area were below one per cent indicates that paddy is the traditional crop in study area. On the other hand, the compound growth rates for production were positive and significant in Bhandara and Gondia district. The highest coefficient of variation for area under paddy was estimated for Chandrapur District 10.92 (per cent) and lowest for Bhandara District 5.04 (per cent) of Eastern Vidarbha region. The cost of Cultivation structure of Paddy indicated that, the most important costly input was human labour which accounted in between 36.29 to 32.31 during five years and on an average 34.50 per cent. The other important items of cost of cultivation are machine labour ( 9.83 per cent), bullock labour ( 7.01 per cent) and fertilizers and manure (11.81 per cent), respectively. The input out ratio was more than one at Cost $\mathrm{A}$ and B. It implies that the crop is profitable at variable cost. But, it is not profitable at cost C. However, there is a chance to get better profit from Paddy cultivation because, firstly, there is less chance of crop failures. Secondly, it is grown in both seasons i.e. kharif \& summer. Thirdly, it is a staple food for rural population. Hence there is a scope to increase qualitative yield in by introducing new development programmes and increase in technical efficiency at farm level.It is further observed that farmers were receiving more than MSP prices during last five years. But the cost of production was higher than MSP. Hence, it is necessary to formulate appropriate price policy for economic development of the paddy farmers.

\section{Introduction}

It is well known that the performance of agricultural sector is very crucial in economic development of most developing countries some is true for India also. More than 60 per cent of Indian population is directly or indirectly dependent on agriculture for its survival. The agriculture sector in India has made tremendous progress after the 'green revolution' and become self sufficient in food-grains. 
Rice (Oryza sativa L.) is an aquatic grass belongs to the family Poaceae. It is native to Tropical and Sub-tropical Southeastern Asia and to Africa. The plant, which needs both warm and moisture to grow, measures 2-6 feet tall and has long, flat, pointy leaves and stalk-bearing spikelets which produce grain known as rice.

Rice is rich in genetic Bio-diversity, with thousands of varieties grown throughout the world. It is life for thousands of millions of people in the globe. It is deeply embedded in the cultural heritage of their societies. About $4 / 5$ of the World's rice is produced by smallscale farmer and is consumed locally.

Rice contributes $42 \%$ of the total food production in India. Rice commended recognition as a supreme commodity to mankind because rice is truly life, culture, tradition and men's livelihood to million. It is an important staple food providing 60-70\% of body calories intake consume.

Rice is the more popular staple food of more than $80 \%$ of the world population. In India rice is grown over 43.39 million hectors with total production of 104.32 million tonnes in the year 2015-16. Rice is an important food crop contributing to more than half the daily requirement of calories. It contains 6 to $7 \%$ proteins and 2 to $5 \%$ fat only. Grain contains calcium and Vitamin in B.

The by-product of rice is used for cattle and poultry feed. Which provide milk and meat for nourishment of human. It is cultivated in both seasons i.e., Kharif \& Summer. In addition to this, it reduces pressure on cereals as well as it may give good returns. Keeping these aspects in view, the objectives of the present study are to estimate growth, instability and economic aspects of Paddy cultivation in Eastern Vidarbha Region of Maharashtra state.

\section{Materials and Methods}

The study was undertaken to examine the growth and extent of deviation from planned acreage.

\section{Collection of Data}

The study was based on district wise secondary data collected for Eastern Vidarbha Zone. The data collected for the period of last 15 years, i.e., from 2004-05 to 2018-19. Data used for the present study was collected from government published sources.

\section{Analytical techniques}

\section{Growth rate analysis}

The compound growth rates of area, production and productivity for Paddy were estimated for all districts of Eastern Vidarbha region. The district-wise compound growth rates was estimated to study the growth. It was estimated on the basis of the following exponential model.

$\mathrm{Y}=\mathrm{a} \cdot \mathrm{b}^{\mathrm{t}}$

$\log Y=\log a+t \log b$

$\mathrm{CGR}=[$ Antilog $(\log \mathrm{b}-1)] \times 100$

Where,

CGR $=$ Compound growth rate

$\mathrm{t}=$ time period in year

$\mathrm{Y}=$ area/ production / productivity

$\mathrm{A} \& \mathrm{~b}=$ Regression parameters

\section{Instability analysis}

To measure the instability in area, production and productivity, an index of instability was used as a measure of variability. 
The Coefficient of variations (CV) was calculated by the following formula

C.V. $($ per cent $)=\frac{\text { Standerd Deviation }}{\text { Mean }} \times 100$

\section{Cost of cultivation of paddy}

The Agricultural Prices and Cost (APC) scheme under the guidance of government of Maharashtra provides valuable data about agriculture in Maharashtra. The data maintained by APC is used in the present study. The recording of data is done by village level investigators through daily visit to the selected farm families.

The scheme is involved in the collection of representative data on input use, yield and there upon estimation of cost of cultivation of principle crops in the region. The present study used cross sectional cum time series. Data of Paddy (kharif) for last Six year, i.e., 2013-14 to 2018-19.

\section{Results and Discussion}

Keeping in view the objectives of the study, the data was analysed using suitable statistical techniques. The results obtained from this study have been presented and discuss critically.

\section{Growth rate}

In this study, the growth in Paddy area, production and productivity were estimated using growth rates as indicated in methodology. In the analysis, the general growth performance of Paddy in all districts of Eastern Vidarbha Zone were examined by fitting exponential growth function with time normalization on area, production and productivity. The growth performance of Paddy is discussed as under.
The perusal of the table 1 , result revealed that the growth rates of area were below one per cent indicating that paddy is the traditional crop in study area. The all districts of the zone were positive compound growth rates except Gondia district.

On the other hand, the compound growth rates for production were positive and significant in Bhandara and Gondia district. The similar result was observed in paddy productivity. The result shows that the compound growth rates of production were increased due to productivity. This indicates the technological impact on paddy production.

\section{Instability in paddy}

One should not obvious of instability by considering the growth rates only. Because the growth rates would explain only the rate of growth over the period, whereas, instability will judge, whether the growth performance is stable or unstable for the period for the pertinent variable. To facilitate better understanding of the magnitude and pattern of changes in the level of production, cropped area and productivity of Paddy in the different seasons in the all districts of Eastern Vidarbha Zone, instability of area, production and productivity of Paddy have been worked out. Fluctuation in area, production and productivity due to the uncontrollable factors like climatic condition can cause an upward bias in coefficient of variation.

Table 2 revealed that the coefficient of variation was higher for the all districts of the Eastern Vidarbha Zone under the production and productivity of paddy. The highest coefficient of variation for area under paddy was estimated for Chandrapur District i.e. 10.92 per cent. On the other hand, it was lowest for Bhandara District $(5.04 \%)$. 
Table.1 District-wise compound growth rates (CGR) for Paddy (Kharif) in Eastern Vidarbha

\begin{tabular}{|l|c|c|c|c|}
\hline DISTRICT & & Area & Production & Productivity \\
\hline Bhandara & & 0.10 & $2.65^{*}$ & $2.54^{*}$ \\
\hline Gondia & -0.52 & & $4.24^{*}$ & $4.79^{*}$ \\
\hline Chandrapur & 0.32 & -0.88 & -1.2 \\
\hline Gadchiroli & $0.83^{*}$ & 1.93 & 1.08 \\
\hline
\end{tabular}

Note: *Significant at $5 \%$ level

\begin{tabular}{|r|l|r|r|r|r|r|r|}
\hline \multicolumn{9}{|c|}{ Table.2 District wise Instability of Paddy (Kharif) In Eastern Vidarbha } \\
\hline Sr No & \multicolumn{1}{|c|}{ District } & \multicolumn{1}{|c|}{ Area (00 ha.) } & \multicolumn{2}{c|}{ Production (00 t.) } & \multicolumn{2}{c|}{ Productivity (kg/ha) } \\
\hline & & Mean & CV \% & Mean & CV \% & Mean & CV \% \\
\hline $\mathbf{1}$ & Bhandara & 1748.13 & 5.04 & 2593.70 & 28.50 & 1478.70 & 27.39 \\
\hline $\mathbf{2}$ & Gondia & 1757.70 & 6.80 & 2638.20 & 31.64 & 1502.10 & 31.41 \\
\hline $\mathbf{3}$ & Chandrapur & 1427.70 & 10.92 & 1708.30 & 34.19 & 1190.70 & 31.73 \\
\hline $\mathbf{4}$ & Gadchiroli & 1516.10 & 6.29 & 1928.30 & 25.70 & 1272.00 & 25.35 \\
\hline
\end{tabular}

\begin{tabular}{|c|c|c|c|c|c|c|c|}
\hline \multicolumn{8}{|c|}{ Table.3 Share of various inputs costs to total cost of Paddy in Eastern Vidarbha } \\
\hline Items & $\begin{array}{l}2013- \\
14\end{array}$ & $\begin{array}{l}2014- \\
15\end{array}$ & $\begin{array}{l}2015- \\
16\end{array}$ & $\begin{array}{l}2016- \\
17\end{array}$ & $\begin{array}{l}2017- \\
18\end{array}$ & 2018-19 & Average \\
\hline Human Labour & 35.59 & 36.29 & 34.99 & 32.31 & 33.35 & 20.27 & 32.13 \\
\hline Bullock Labour & 7.53 & 6.86 & 6.89 & 7.5 & 6.31 & 5.87 & 6.83 \\
\hline Machine Labours & 9.33 & 9.64 & 9.95 & 9.73 & 10.5 & 8.13 & 9.55 \\
\hline Seed & 4.3 & 5.03 & 5.22 & 4.36 & 4.3 & 3.20 & 4.40 \\
\hline $\begin{array}{l}\text { Manure \& Fertilizer / } \\
\text { Biofertilizer }\end{array}$ & 12.73 & 12.5 & 11.9 & 11.87 & 10.09 & 7.87 & 11.16 \\
\hline insecticide \& Weedicide & 1.69 & 2.39 & 1.99 & 3.12 & 2.36 & 3.51 & 2.51 \\
\hline $\begin{array}{l}\text { Incidental Charges \& } \\
\text { Repairs }\end{array}$ & 2.76 & 2.42 & 3.17 & 6.31 & 6.41 & 6.16 & 4.54 \\
\hline $\begin{array}{l}\text { Interest on working } \\
\text { Capital }\end{array}$ & 3.95 & 4.01 & 3.99 & 3.79 & 3.74 & 3.33 & 3.80 \\
\hline Operation Cost & 77.88 & 79.14 & 79.02 & 78.99 & 77.06 & 62.65 & 75.79 \\
\hline Rental value of Land & 16.92 & 15.54 & 15.68 & 10.49 & 15.48 & 9.19 & 13.88 \\
\hline $\begin{array}{l}\text { Land Revenue cess \& } \\
\text { taxes }\end{array}$ & 0.04 & 0.05 & 0.05 & 0.25 & 0.03 & 0.03 & 0.08 \\
\hline $\begin{array}{l}\text { Depreciation in } \\
\text { implements \& farm } \\
\text { building }\end{array}$ & 1.84 & 1.9 & 2.22 & 2.75 & 2.34 & 3.76 & 2.47 \\
\hline Int. On Fixed Capital & 3.32 & 3.37 & 3.98 & 7.49 & 5.09 & 17.50 & 6.79 \\
\hline fixed cost & 22.12 & 20.86 & 21.93 & 20.98 & 22.94 & 37.35 & 24.36 \\
\hline
\end{tabular}




\begin{tabular}{|c|c|c|c|c|c|c|c|}
\hline \multicolumn{8}{|c|}{ Table. 4 Cost of cultivation, value of output and income of paddy } \\
\hline Items & $\begin{array}{l}2013-14 \\
(n=180)\end{array}$ & $\begin{array}{l}2014-15 \\
(n=168)\end{array}$ & $\begin{array}{l}2015-16 \\
(n=156)\end{array}$ & $\begin{array}{l}2016-17 \\
(n=136)\end{array}$ & $\begin{array}{l}2017-18 \\
(n=113)\end{array}$ & $\begin{array}{l}2018-19 \\
(n=143)\end{array}$ & Average \\
\hline \multicolumn{8}{|l|}{ Yield (Qtls) } \\
\hline Main Produce & 29.92 & 23.23 & 25.70 & 23.43 & 33.47 & 23.13 & 26.48 \\
\hline By Produce & 35.33 & 29.2 & 32.23 & 31.00 & 42.34 & 30.83 & 33.49 \\
\hline \multicolumn{8}{|c|}{ Value of Produce } \\
\hline Main Produce & 44129.87 & 42243.68 & 46024.82 & 37482.47 & 52755.02 & 39500.25 & 43689.35 \\
\hline By Produce & 2665.16 & 2245.28 & 2430.62 & 2684.57 & 3234.09 & 2701.41 & 2660.19 \\
\hline Total & 43278.26 & 45326.08 & 49081.07 & 59744.07 & 57292.09 & 42201.66 & 49487.21 \\
\hline \multicolumn{8}{|l|}{ Total cost } \\
\hline $\operatorname{Cost}^{~ ' A '}$ & 32915.14 & 34631.60 & 36547.50 & 43742.59 & 41523.18 & 47781.41 & 39523.57 \\
\hline Cost 'B' & 42220.01 & 43627.01 & 46825.30 & 54949.86 & 53915.47 & 68136.91 & 51612.43 \\
\hline $\operatorname{Cost}^{\prime} \mathrm{C}^{\prime}$ & 45943.42 & 47571.36 & 51511.70 & 62428.64 & 60526.18 & 76270.78 & 57375.35 \\
\hline \multicolumn{8}{|l|}{ Net return over } \\
\hline $\operatorname{Cost}^{\prime} \mathbf{A}^{\prime}$ & 10363.12 & 10694.48 & 12533.57 & 16001.48 & 15768.91 & -5579.71 & 9963.64 \\
\hline Cost 'B' & 1058.25 & 1699.07 & 2255.77 & 4794.21 & 3376.62 & -25935.21 & -2125.22 \\
\hline $\operatorname{Cost}^{\prime} \mathrm{C}^{\prime}$ & -2665.16 & -2245.28 & -2430.63 & -2684.57 & -3234.09 & -34069.08 & -7888.14 \\
\hline \multicolumn{8}{|c|}{ Input-output Ratio at } \\
\hline $\operatorname{Cost}^{\prime} \mathbf{A}^{\prime}$ & 1.31 & 1.30 & 1.34 & 1.36 & 1.37 & 0.88 & 1.26 \\
\hline Cost 'B' & 1.02 & 1.03 & 1.04 & 1.08 & 1.06 & 0.62 & 0.98 \\
\hline $\operatorname{Cost}^{\prime} C^{\prime}$ & 0.94 & 0.95 & 0.95 & 0.95 & 0.94 & 0.55 & 0.88 \\
\hline
\end{tabular}

\begin{tabular}{|c|l|r|r|r|r|r|r|r|}
\hline \multicolumn{8}{|c|}{ Table.5 Comparison between producer price, cost of production, and MSP } \\
\hline Sr. No & ITEMS & $2013-14$ & $2014-15$ & $2015-16$ & $2016-17$ & $2017-18$ & $2018-19$ & Average \\
\hline $\mathbf{1}$ & $\begin{array}{l}\text { Producer Price (Rs. / } \\
\text { Qtl.) }\end{array}$ & 1474.93 & 1818.42 & 1790.85 & 1599.76 & 1576.19 & 1707.75 & 1661.32 \\
\hline $\mathbf{2}$ & $\begin{array}{l}\text { Cost of Production } \\
\text { (Rs./Qtl) }\end{array}$ & 1446.47 & 1951.10 & 1909.77 & 2549.90 & 1711.74 & 3180.69 & 2124.95 \\
\hline $\mathbf{3}$ & MSP (Rs./Qtls) & 1310.00 & 1360.00 & 1410.00 & 1470.00 & 1550.00 & 1770.00 & 1478.33 \\
\hline $\mathbf{4}$ & $\begin{array}{l}\text { Parity between Cost \& } \\
\text { MSP }\end{array}$ & $\mathbf{1 3 6 . 4 7}$ & $\mathbf{5 9 1 . 1 0}$ & $\mathbf{4 9 9 . 7 7}$ & $\mathbf{1 0 7 9 . 9 0}$ & $\mathbf{1 6 1 . 7 4}$ & $\mathbf{1 4 1 0 . 6 9}$ & $\mathbf{6 4 6 . 6 1}$ \\
\hline $\mathbf{5}$ & $\begin{array}{l}\text { \% of Producer price } \\
\text { over MSP }\end{array}$ & 112.59 & 133.71 & 127.01 & 108.83 & 101.69 & 96.48 & 113.39 \\
\hline $\mathbf{6}$ & $\begin{array}{l}\text { \% Change over } \\
\text { Previous year (CoP) }\end{array}$ & 134.89 & 97.88 & 133.52 & 67.13 & 185.82 & 123.85 \\
\hline $\mathbf{7}$ & $\begin{array}{l}\text { \% Change over } \\
\text { Previous year (MSP) }\end{array}$ & & 103.81 & 103.67 & 104.25 & 105.44 & 114.19 & 106.27 \\
\hline
\end{tabular}

The coefficient of variation for productivity of Gadchiroli district was lowest $(25.35 \%)$. While the coefficient of variation for productivity of Chandrpur was highest (31.73 $\%)$. Table 2 Indicates that the average area of last 15 years under paddy cultivation was higher in Gondia district (177500 ha) and the lowest area covered in Chandrapur district (142100 ha). The kharif paddy has cultivated in the large area in Gondia and Bhandara 
district of Vidarbha region due to high rainfall.

\section{Variation in cost of cultivation structure}

Farming as a business is greatly influenced by the level and structure of cost of cultivation. The share of various input cost to total cost of Paddy in Eastern Vidarbha region is presented in Table 3.

Table 3 revealed that, in paddy cultivation, the most important costly input was human labour which accounted in the range between 36.29 and 20.27 per cent during Six year and on average $32.13 \%$. The other important items of cost of cultivation were Fertilizer and manure $(11.16 \%)$, machinery labour $(9.55 \%)$ and bullock labour $(6.83 \%)$ respectively. The relative shares of these items were more or less some from year to year. All these variable cost items together accounted for 75.79per cent as an average of last Six years.

The share of operational cost recorded higher than fix cost. However, among the items of fixed cost, the share of the rental value of owned land was found high compared to other items like land revenue, depreciation on implement and interest on fixed capital.

\section{Profitability analysis of paddy (kharif) cultivation}

During the last few years, the area under Paddy in all districts of Eastern Vidarbha Zone was decreasing, there is chance to get better profit from paddy cultivation because, first, there is less chance of crop failures. Second, it is grown in both seasons. Third, it is a staple food for rural population and fourth, it gives fodder for livestock in the region. With this background, let us now find out whether the farmer get profit or not from paddy cultivation by using cost of cultivation survey data.
Table 4 indicates that the Paddy cultivators Eastern Vidarbha Zone able to make profit during 2013-14 to 2017-18 in relation to cost 'A'. Netreturn over Cost 'A' has been recorded positive for all most all the years with range in between 1.30 to 1.37 . The Table further reveals that, the input - output ratio at cost ' $\mathrm{B}$ ' were more than one for all years except 2018-19, while in 2016-17 the ration of cost ' $\mathrm{B}$ ' was highest. The input-output ratio at cost ' $\mathrm{C}$ ' for year 2014-15, 2015-16 and 2016-17 is 0.95 where 2013-14 and 2017-18 is 0.94. However, the lowest input-output ratio was measured during 2018-19. It is clear from the above discussion that, during last six year, the Paddy cultivation was nonprofitable, However, the profitability could be improved by introducing new technology with higher yielding drought resistant varieties.

\section{Comparative analysis between producer' sprice, cost of production, and MSP}

Table 5 indicates the comparison between producer price, cost of cultivation and Minimum Support price of Paddy in Eastern Vidarbha region. It is observed that farmers were receiving better price as compared to the MSP. But, the cost of production was much more than MSP. The parity between cost of production and MSP price was range from Rs. 136.47 to Rs. 1410.69 during last six years. Hence it is necessary to fixed the MSP on the cost of production for the paddy.

The study further indicates that on an average, the percentage of cost of production over previous year was increased by $23.85 \%$ on an average of last five year. However, the MSP was increased only by $6.27 \%$.

In conclusion the input out ratio was more than one at Cost A and B. It implies that the crop is profitable at variable cost. But, it is not profitable at cost $\mathrm{C}$. However, there is a chance to get better profit from Paddy 
cultivation because, firstly, there is less chance of crop failures. Secondly, it is grown in both seasons i.e. kharif \& summer. Thirdly, it is a staple food for rural population. Hence there is a scope to increase qualitative yield by introducing new development programmes and increase in technical efficiency at farm level.It is further observed that farmers were receiving more than MSP prices during last five years. But the cost of production was higher than MSP. Hence, it is necessary to formulate appropriate price policy for economic development of the paddy farmers in Eastern Vidarbha Zone.

\section{References}

Anonymous 2017.Annual report 2017-18 website http//www.krishi. Maharashtra. gov.in

Goyal S. K., 2008. Growth and instability in revised export marketing of onion. Indian J. Agril. Mktg. 22-(3): 11-18.

Havaldar Y.N., S.N. Megeri., S.B. Hosamni and Basavraj Bankar, 2011. Growth rate scenario of chilli in north Karnataka. Karnataka. J. Agric. Sci. 24-(3):412.

Immanuelraj, T.K., M.B. Dastagiri and Sajesh V.K., 2014. Growth and Instability of Onion Production in Maharashtra. Indian J. of Global Econ. 2-(1): 1-4.

Kondal, K., 2014. Growth Rate of Area, Production and Productivity of Onion Crop in Andhra Pradesh. Indian J. of Applied Research.4-(3): 4-6.

Kalamkar, S.S., Shende, N.V. and Atkare, V.G. 2002. Coarse cereals and pulses production in India: Trends and Decomposition analysis. Agril. Situation in India 59-(1): 581-587.

Sakamma, S. and G.S. Ananth., 2011. Growth and instability in production and export of major spices of India: an economic analysis. Green Farming.2-(5): 615617.

Shende N. V. 2002. Impact of price on acreage of major crops. Indian Journal of Agricultural Marketing. 16-(2) 102106.

Shende N. V. and Suryawanshi G. K. 2009 Growth, Instability and Decomposition of cotton production in Maharashtra. Journal of Cotton Research\& Development. 23-(2) 325-337

Shende N. V., Ganvir B. N. and Thakare S. S. 2011. Growth and instability of selected crop in Western Vidarbha. International Research Journal of Agriculture Economics \& Statictics, 2-(1) 19-27

Shende N. V., Thakare S. S. and RaundalP. S. 2011 "Decomposition analysis and acreage response of soybean in Western Vidarbha" Journal of Food Legumes 24(2) 133-137

Shende N. V. and Bagde N. T. 2018 "Growth Dynamics and Profitability of Sorghum in Vidharbh Region of Maharashtra', Agriculture Situation in India. 75-(2) 11-19

Thorat V, T. Singh and B. Ghule. 2012 Dynamics of area, production and export of grapes in India, A performance analysis. Lambert Academic Publishing. 13:978

\section{How to cite this article:}

Nishant V. Shende. 2020. Impact of Prices on Paddy Performance in Eastern Vidarbha Zone. Int.J.Curr.Microbiol.App.Sci. 9(08): 2993-2999. doi: https://doi.org/10.20546/ijcmas.2020.908.337 